\title{
KALIMANTAN TIMUR : DAERAH KAYA VERSI SIAPA?
}

\author{
Oleh: Erny Murniasih ${ }^{1}$
}

\begin{abstract}
The simplest way to understand decentralisation is bringing the government closer to its people. From the economic view, the implementation of decentralisation will improve in economic efficiency, service delivery, and accountability. In Indonesia, decentralisation has developed in form of political, fiscal, and administrative decentralisation. In fiscal decentralisation, the country applies the money follows function principle as a means to give fiscal balance between central and sub-national governments. Therefore,SNG's are granted with local-own sources and intergovernmental fiscal transfers to finance the assigned functions. The main objective for fiscal decentralisation is to increase welfare at the local level. To what extent that this occur in Province East Kalimantan? The fact that the Province has a substantial revenue from natural resources which makes its GRDP increased.

Theoretically, an increase in GRDP will affect on the increase number of employment and on the reduction of the poor. However, what has happened in East Kalimantan is on the reverse side. Increase in GRDP does not necessarily reveal that the people, particularly the poor, would be better-off. This paper tries to analyse the case and provides with possible solution.
\end{abstract}

Keywords : Desentralisasi Fiskal, Dana Perimbangan, Dana Bagi Hasil Sumber Daya Alam

\section{Pendahuluan}

Pelaksanaan desentralisasi dan otonomi daerah di Indonesia sejak tahun 2001 ditandai oleh pemberian wewenang dan diskresi kepada Daerah untuk melaksanakan fungsi-fungsi pemerintahan. Di banyak negara, desentralisasi dilakukan sebagai instrumen untuk memperbaiki tingkat pelayanan kepada masyarakat dan juga sebagai alat untuk mewujudkan demokrasi. Untuk itu, kesejahteraan masyarakat merupakan tujuan utama dari sebuah program desentralisasi. Hal ini karena pemerintah daerah lebih dekat dengan komunitas lokal dan lebih mengetahui kebutuhan lokal, sehingga esensi sebuah program desentralisasi merupakan upaya untuk mendekatkan pemerintah kepada masyarakat, atau yang sering kita dengar dengan istilah 'bringing the government closer to its people'.

Program desentralisasi di Indonesia dilaksanakan dengan melalui tiga dimensi pokok, yaitu desentralisasi politik, desentralisasi fiskal, dan desentralisasi administrasi. UU nomor 32 tahun 2004 tentang Pemerintahan Daerah menegaskan pemberian kewenangan yang seluas-luasnya kepada daerah disertai dengan pemberian hak dan kewajiban menyelenggarakan otonomi daerah dengan memperhatikan harmonisasi hubungan antarsusunan pemerintahan dan antarpemerintahan daerah, potensi dan keanekaragaman daerah, peluang dan tantangan persaingan global dalam satu kesatuan sistem penyelenggaraan pemerintahan negara.

Merujuk filosofi pelaksanaan desentralisasi tersebut di atas, maka paradigma bahwa daerah merupakan bagian dari negara kesatuan Republik Indonesia diintegrasikan secara

\footnotetext{
${ }^{1}$ Erny adalah staf pada Departemen Keuangan. Opini yang disampaikan dalam makalah ini merupakan pendapat pribadi dan tidak terkait dengan pendapat institusi.
} 
lugas ke dalam program desentralisasi yang mengedepankan prinsip demokrasi, pembagian fungsi pemerintahan, dan pemberian kewenangan keuangan. Dalam hal desentralisasi fiskal, kepada daerah diberikan sumber-sumber pendapatan dalam rangka melaksanakan kewenangan yang telah diserahkan kepada daerah.

UU No. 33 tahun 2004 tentang Perimbangan Keuangan memberikan amanat kepada daerah untuk mengoptimalkan penerimaan yang bersumber dari potensi sumber daya yang ada di daerah, yakni dalam bentuk pajak daerah dan retribusi daerah. Selain itu, untuk mengurangi ketimpangan keuangan yang terjadi antardaerah maka mekanisme transfer dalam bentuk dana perimbangan -yang terdiri dari Dana Bagi Hasil (DBH), Dana Alokasi Umum (DAU), dan Dana Alokasi Khusus (DAK) - juga diberikan kepada daerah.

Di awal pelaksanaan otonomi daerah, isu dan nuansa ketimpangan fiskal antardaerah sangat kental disuarakan, terutama mengenai ketimpangan yang terjadi antara daerah kaya penghasil sumber daya alam dengan daerah yang tidak memiliki potensi sumber daya alam. Mekanisme dana bagi hasil dalam dana perimbangan menjadi pemicu terjadinya ketimpangan fiskal tersebut. Untuk itu, dana alokasi umum -yang merupakan satu paket kebijakan dana perimbangan- dikucurkan kepada daerah dengan tujuan untuk mengatasi ketimpangan horisontal yang terjadi antardaerah. Namun demikian, performa formula DAU sebagai alat untuk meredam potensi ketimpangan fiskal horisontal sampai saat ini masih belum memenuhi harapan yang optimal.

Murniasih (2006) dalam studinya tentang 'new equalisation grant system in Indonesia' menemukan bahwa formula DAU yang baru sebagaimana diamanatkan oleh UU No. 33 tahun 2004 hanya memberikan koreksi terhadap permasalahan ketimpangan fiskal horisontal di tingkat kabupaten/kota, namun tidak demikian halnya dengan level provinsi. Warisan kesenjangan yang cukup besar di masa lalu menjadikan performa DAU sebagai alat untuk mencapai keseimbangan horisontal di tingkat provinsi menjadi cukup sulit. Kesenjangan yang terjadi antarprovinsi terutama disebabkan oleh kesenjangan dalam hal optimalisasi PAD dan alokasi DBH.

Provinsi Kalimantan Timur sebagai salah satu daerah penghasil sumber daya alam mendapatkan bagi hasil yang signifikan bila dibandingkan dengan daerah lain yang tidak memiliki sumber daya alam. Secara rata-rata, jumlah penerimaan dana bagi hasil sumber daya alam yang diterima Provinsi Kaltim sejak tahun 2001 hingga 2007 mencapai 68 persen terhadap total dana perimbangan. Sedangkan kontribusi Pendapatan Asli Daerah (PAD) terhadap total penerimaan juga cukup memadai yaitu sekitar 23 persen.

Seiring dengan tingginya penerimaan dari DBH SDA tersebut, tingkat pertumbuhan ekonomi yang dicerminkan oleh Produk Domestik Regional Bruto (PDRB) juga mengalami peningkatan. Namun demikian, kenaikan tersebut tidak berpengaruh terhadap kondisi sosial di masyarakat. Tingkat pengangguran terbuka dan jumlah penduduk miskin malah mengalami peningkatan.

Kondisi-kondisi tersebut memicu pertanyaan, mengapa peningkatan pertumbuhan ekonomi di Provinsi Kaltim tidak diiringi oleh meningkatnya jumlah tenaga kerja dan menurunnya angka kemiskinan? Untuk itulah mengapa masih ada ungkapan bahwa Provinsi Kaltim adalah daerah yang kaya, tetapi menurut versi siapa?

Makalah ini akan mencoba menganalisa persoalan tersebut dari perspektif penerimaan dan pengeluaran serta analisa terhadap kapasitas fiskal dengan indikator ekonomi dan sosial masyarakat di Kalimantan Timur. Tujuan penulisan makalah ini adalah untuk memberikan masukan tentang bagaimana mengoptimalkan sumber daya alam dan manusia yang ada di Kalimantan Timur demi kesejahteraan komunitas lokal. 


\section{Program Desentralisasi sebagai Stimulan Pembangunan Daerah}

Pergeseran dari sebuah perencanaan sentralistis menuju sistem pemerintahan yang desentralistis telah menyebar hampir keseluruh negara pada era tahun 1980-an. Di negaranegara Asia Timur, tren desentralisasi hampir menyebar ke semua penjuru kawasan tersebut (White dan Smoke, 2005). Di Indonesia, program tersebut lebih populer dengan istilah 'the big bang decentralisation program' yang diperkenallkan pada awal tahun 2000. Sementara itu, di Cambodia dan Vietnam juga diperkenalkan program desentralisasi yang dilakukan secara bertahap.

Bagi negara berkembang, program desentralisasi dapat dilihat sebagai sebuah 'panacea' yaitu penyembuhan terhadap penyakit yang sudah kronis, atau malah sebagai 'plague' yaitu menambah beban atas penyakit yang telah diderita sejak lama (Bird dan Vaillancourt, 1999).

Dorongan dan pertimbangan untuk mengaplikasikan program desentralisasi pada suatu negara tergantung pada konteks institusi, politik, dan ekonomi serta latar belakang sejarah dan tradisi negara tersebut. Menurut Tanzi (2002), pelaksanaan desentralisasi didorong oleh beberapa driving-forces (faktor pendorong) yaitu dorongan dari internal (seperti desakan untuk mempraktekan demokrasi atau desakan untuk meningkatkan kesejahteraan), dan/atau dorongan dari eksternal (seperti desakan dari negara/lembaga donor).

Berdasarkan penelitian White dan Smoke (2005) terhadap tren desentralisasi fiskal di negara-negara Asia Timur, beberapa faktor utama yang mendorong pergeseran dari sentralisasi ke desentralisasi adalah faktor ekonomi, perubahan demografi, dan politik. Di Indonesia, semangat reformasi pada tahun 1999 setelah lengsernya mantan penguasa nomor satu di era orde baru telah menghasilkan sebuah produk kebijakan yang dampak multiplier effect nya sangat besar, yaitu sebuah program desentralisasi.

Pakar pro-desentralisasi mengungkapkan bahwa pelaksanaan desentralisasi akan meningkatkan efisiensi ekonomi, efisiensi biaya, peningkatan akuntabilitas, dan peningkatan mobilisasi sumber-sumber daya. Namun demikian, pakar lain yang kontra dengan pelaksanaan desentralisasi mengemukakan bahwa desentralisasi malah berdampak pada meningkatnya biaya, inefisiensi penyediaan layanan, dan kemungkinan akan berdampak pada semakin tingginya tingkat ketidakmerataan (inequality) serta ketidakstabilan makroekonomi (Prud'homme dalam Bird dan Vaillancourt, 1999).

Untuk mengantisipasi bahaya yang ditimbulkan dari kesalahan pelaksanaan program desentralisasi maka peranan kepemimpinan nasional sangat krusial untuk merespon secara konsisten dan sistematis terhadap potensi kegagalan desentralisasi (White dan Smoke, 2005).

Sebelum memulai analisa terhadap pelaksanaan desentralisasi (khususnya desentralisasi fiskal) di Provinsi Kalimantan Timur, ada baiknya bila dalam bagian ini juga dibahas mengenai definisi dan pengertian terhadap konsep desentralisasi itu sendiri agar kesamaan persepsi dapat dicapai.

Dalam teori keuangan negara, dikenal pengertian desentralisasi berdasarkan tiga dimensi pokok, yaitu desentralisasi politik, desentralisasi fiskal, dan desentralisasi administrasi (nn, 2005). Dalam desentralisasi politik, penyerahan kewenangan politik dari pemerintah pusat kepada pemerintah daerah melalui penegakan atau pembentukan kembali pemerintahan daerah yang dipilih melalui pemilihan umum. Untuk itu, dalam pelaksanaan desentralisasi politik juga dilakukan langkah-langkah reformasi pemilihan umum daerah, reformasi partai politik, serta pemberian hak untuk berpartisipasi. Di Indonesia, 
pelaksanaan desentralisasi politik ditandai dengan diakuinya daerah sebagai entitas tersendiri yang berhak mengatur dan mengurus rumah tangganya serta melaksanakan fungsi-fungsi pemerintahan. Untuk itu, pemerintahan daerah dipilih melalui sebuah pemilihan umum langsung baik untuk tingkat eksekutif dan legislatif daerah. Dengan demikian proses demokrasi di daerah dapat berlangsung serta partisipasi rakyat dalam pembangunan daerah dapat terlaksana.

Sementara itu, desentralisasi fiskal mengandung pengertian pemindahan kekuasaan fiskal yang terpusat kepada pemerintahan daerah (regional dan lokal) dengan melalui beberapa hal antara lain meningkatkan atau menurunkan kondisi transfer sumber daya antardaerah dan memberikan kekuasaan kepada pemerintahan daerah untuk menghasilkan sumber-sumber pendapatannya sendiri. Pemindahan kekuasaan tersebut juga diiringi dengan kewenangan untuk memungut pajak, melakukan penyusunan anggaran dan pengeluaran anggaran, serta hal-hal yang terkait dengan pengalokasian dana antar pemerintahan. Pelaksanaan desentralisasi fiskal di Indonesia berdasarkan UU No. 33 tahun 2004 menganut prinsip 'money follows functions' dimana kewenangan fiskal diserahkan kepada daerah sesuai dengan penyerahan urusan pemerintahan dari pusat kepada daerah.

Desentralisasi administrasi melibatkan pemindahan sebagian atau seluruh tanggung jawab fungsional pemerintahan kepada tingkat regional dan daerah. Dalam desentralisasi administrasi, perencanaan dan pelaksanaan berada pada tingkat regional dan daerah sehingga lebih menjangkau layanan kepada grassroot level, sebagai contoh pelayanan kesehatan masyarakat, pembangunan jalan, dan lain sebagainya.

Selain itu, pengertian desentralisasi dapat pula dibedakan berdasarkan tingkat pengambilan keputusan. Bird dan Vaillancourt (1999) membedakan pengertian desentralisasi berdasarkan tiga tingkatan yaitu : Devolusi, Dekonsentrasi, dan Delegasi. Dalam devolusi, tanggung jawab pengambilan keputusan berada di level pemerintahan daerah. Dengan demikian, pemerintah daerah secara fundamental bertanggung jawab penuh kepada komunitas lokal.

Sedangkan dekonsentrasi merupakan pemindahan pelaksanaan urusan pemerintah pusat kepada instansi vertikal yang berada di daerah atau unit organisasi pemerintah daerah. Instansi vertikal dan unit organisasi pemda tersebut mempunyai tanggung jawab untuk melaksanakan pemberian pelayanan kepada masyarakat lokal. Namun demikian kedua unit tersebut harus memberikan pelaporan kepada pemerintah pusat mengenai pelaksanaan program dekonsentrasi. Sementara itu, delegasi merupakan transfer tanggung jawab manajerial ke sebuah lembaga yang telah didesain secara khusus yang berada diluar struktur pemerintahan pusat.

Di Indonesia, pola hubungan keuangan antara pusat dan daerah disusun sebagai sebuah sistem perimbangan keuangan antara pusat dan daerah berdasarkan asas desentralisasi, dekonsentrasi, dan tugas pembantuan. Prinsip money follows function yang melekat pada pelaksanaan desentralisasi fiskal kemudian diberikan dalam bentuk penguatan taxing power kepada daerah serta mekanisme tranfer dan pembiayaan pembangunan.

Secara umum, program desentralisasi fiskal di Indonesia untuk tahun 2008 diupayakan untuk mengurangi kesenjangan fiskal antara pusat dan daerah, dan antardaerah, meningkatkan kualitas pelayanan publik di daerah dan mengurangi kesenjangan publik antardaerah, mendukung kesinambungan fiskal dalam kebijakan ekonomi makro, meningkatkan kapasitas daerah dalam menggali potensi ekonomi daerah, meningkatkan efisiensi pemanfaatan sumber daya nasional, meningkatkan transparansi dan akuntabilitas 
alokasi belaja ke daerah, serta meningkatkan sinergi perencanaan pembangunan pusat dan daerah.

Dengan demikian, sistem perimbangan keuangan antara pusat dan daerah merupakan bagian integral dari keuangan negara yang bertujuan untuk meningkatkan kesejahteraan rakyat dengan mengembangkan kesinambungan dan pemerataan pembangunan antardaerah.

\section{Potensi Sumber Penerimaan Provinsi Kalimantan Timur}

Sebelum era desentralisasi dan otonomi daerah, seluruh penerimaan yang berasal dari penambangan minyak bumi dan gas harus disetorkan kepada negara. Daerah penghasil hanya mendapatkan subsidi dari pemerintah pusat. Pada era tersebut ketimpangan fiskal yang terjadi antara pusat dan daerah sangat besar. Pembangunan pun hanya terkonsentrasi pada daerah-daerah tertentu, terutama di pulau jawa. Provinsi Kalimantan Timur sebagai salah satu penghasil penerimaan terbesar dari sektor pertambangan terkondisikan sebagai daerah marjinal.

Dalam rangka pelaksanaan desentralisasi fiskal, daerah diberikan sumber-sumber penerimaan. Menurut Boex (1999), elemen penting yang merupakan pilar pelaksanaan desentralisasi fiskal dari sisi penerimaan daerah adalah revenue assignment (kewenangan untuk memungut pajak), intergovernmental fiscal transfers (transfer dana), dan subnational borrowing (pinjaman daerah).

Di Indonesia berdasarkan UU No. 33 tahun 2004, daerah diberikan sumber-sumber penerimaan yaitu : Pendapatan Asli Daerah (PAD), transfer dana berupa dana perimbangan, dana otonomi khusus dan dana penyesuaian, serta pinjaman daerah. Sebagaimana disebutkan di muka, alokasi dana perimbangan terdiri dari DBH (dari pajak dan sumber daya alam), DAU, dan DAK.

Provinsi Kalimantan Timur merupakan daerah yang dianugerahi kekayaan sumber daya alam yang melimpah, mulai dari minyak bumi, gas, batubara, dan barang tambang lainnya. Tidak hanya itu kondisi tanah yang subur memungkinkan pula bagi tumbuhnya sektor pertanian dan perkebunan di Provinsi tersebut, seperti perkebunan kelapa sawit.

Berdasarkan potensi sumber daya alam yang besar tersebut maka Provinsi Kalimantan Timur mendapatkan porsi alokasi dana bagi hasil yang cukup signifikan untuk melaksanakan tugas-tugas pemerintahan yang telah diserahkan dalam rangka pelaksanaan desentralisasi. Grafik 1 menggambarkan tren alokasi dana perimbangan (DBH, DAU, dan DAK) yang diterima oleh Provinsi Kalimantan Timur sejak tahun anggaran 2001 sampai dengan 2007.

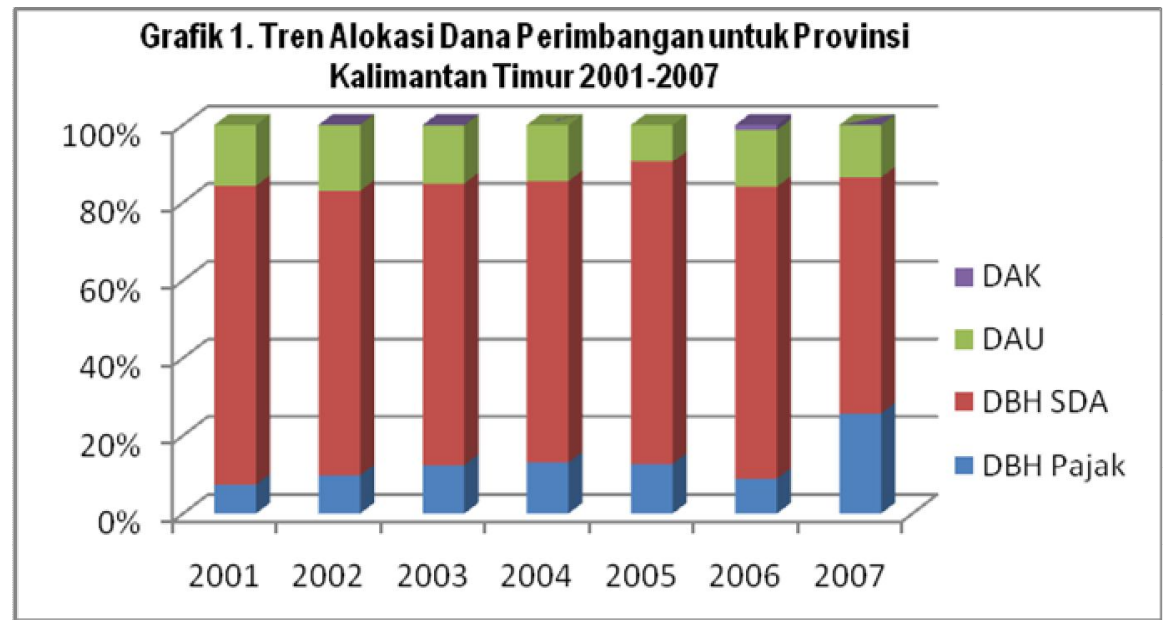


Sumber : Departemen Keuangan; diolah. Data tahun 2001-2006 merupakan angka realisasi, sedangkan data tahun 2007 merupakan angka dalam APBD.

Dari grafik tersebut terlihat bahwa DBH sumber daya alam memberikan porsi yang terbesar terhadap alokasi dana perimbangan untuk Provinsi Kaltim. Sejak tahun 2001 sampai dengan 2007, kontribusi penerimaan Provinsi Kaltim yang bersumber dari DBH sumber daya alam mencapai rata-rata 52 persen terhadap total pendapatan dalam APBD dan sebesar 68 persen terhadap total dana perimbangan.

Secara lebih spesifik, pada dasarnya perolehan alokasi DBH SDA secara persentase mengalami fluktuasi kenaikan dan penurunan dari tahun ke tahun. Pada tahun 2002, realisasi penerimaan DBH SDA mengalami penurunan sebesar 6 persen dibandingkan dengan realisasi penerimaan pada tahun 2001. Namun pada tahun-tahun selanjutnya hingga tahun 2005 mengalami peningkatan yang cukup signifikan yaitu rata-rata sebesar 28 persen. Kemudian pada tahun 2006 realisasi penerimaan mengalami penurunan yang cukup drastis yaitu sebesar 43 persen, dan pada tahun 2007 diperkirakan akan mengalami penurunan sebesar 11 persen dibandingkan dengan realisasi tahun 2006. Sementara itu, estimasi untuk penerimaan tahun 2008 dimungkinkan mengalami penurunan seiring dengan menurunnya estimasi alokasi DBH SDA secara nasional.

Di lain sisi, DAU -yang merupakan sumber yang paling dominan di banyak daerah- ternyata hanya memberikan kontribusi sekitar 10 persen terhadap total pendapatan Provinsi Kaltim. Begitu pula dengan DAK yang hanya memberikan sedikit kontribusi terhadap pendapatan Kaltim. Apabila dihitung secara agregat maka kontribusi dana perimbangan terhadap total pendapatan dalam APBD selama enam tahun terakhir menunjukkan angka persentase sebesar rata-rata 70 persen.

Hal ini menunjukkan bahwa pendapatan provinsi Kalimantan Timur sangat tergantung dari DBH SDA. Terlebih lagi bila angka persentase tersebut dibandingkan dengan kemampuan pemda dalam memobilisasi sumber-sumber penerimaan dari Pendapatan Asli Daerah (PAD). Sejak tahun 2001-2006, kontribusi PAD terhadap total pendapatan dalam APBD rata-rata mencapai 23 persen. Dari persentase tersebut, penerimaan dari sektor perpajakan daerah memberikan kontribusi yang cukup signifikan, yaitu rata-rata sebesar 69 persen. Sementara itu, retribusi daerah memberikan kontribusi rata-rata sebesar 13 persen, sisanya adalah kontribusi dari laba perusahaan daerah dan lainlain PAD.

Kondisi tersebut mencerminkan bahwa potensi penerimaan dari PAD, terutama dari pajak daerah, memberikan indikasi sumber penerimaan yang potensial bila dilakukan secara intensif. Grafik 2 memberikan gambaran mengenai fitur perolehan PAD di Provinsi Kaltim selama tahun 2001 sampai dengan 2006. 


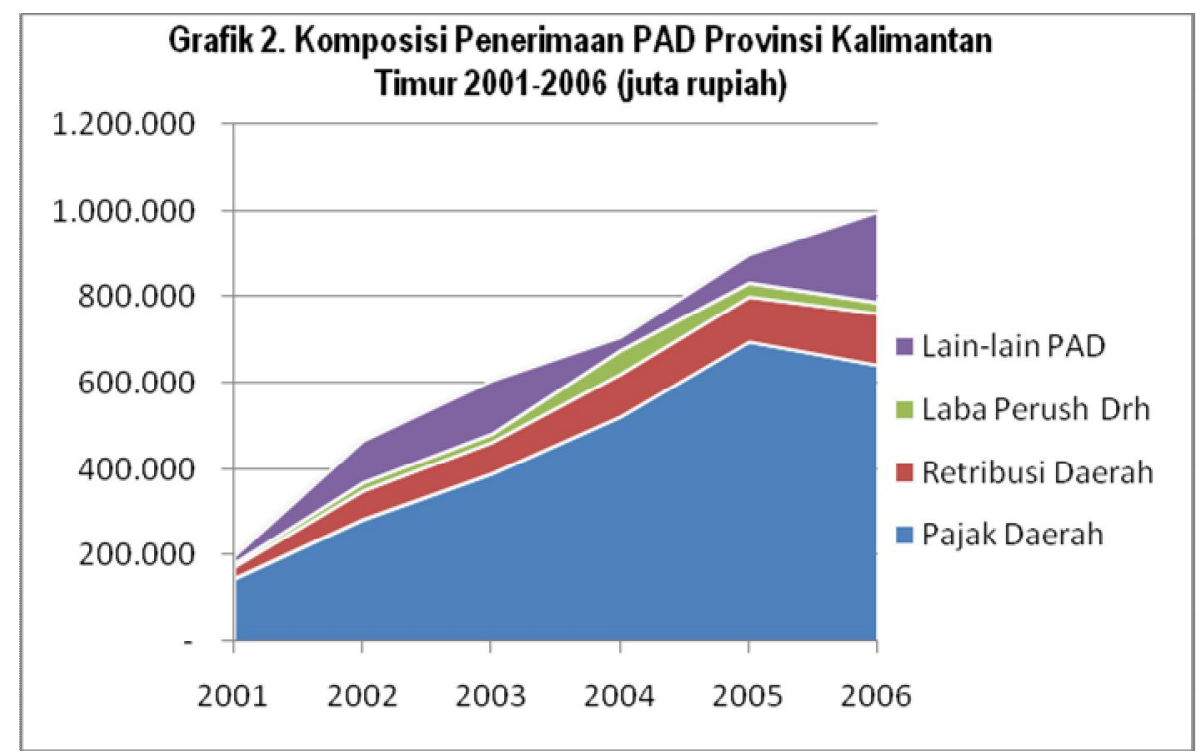

Sumber : Data APBD, Departemen Keuangan (2007; diolah)

Mencermati penerimaan Provinsi Kaltim yang lebih bertumpu pada alokasi dana perimbangan, terutama dari DBH SDA, maka pemda Provinsi Kaltim selaku pengguna anggaran di daerah harus dapat melakukan perencanaan keuangan secara efektif dan efisien.

Disadari pula bahwa ketergantungan penerimaan dari sumber daya alam akan berdampak pada ekonomi dan sosial yang cukup tinggi, terutama mengingat sifat dari sumber daya alam tersebut yang dapat habis sewaktu-waktu dan tidak ada yang dapat memprediksikan secara akurat mengenai jumlah pasokan yang tersedia. Untuk itu, diversifikasi sumber penerimaan baru dan intensifikasi sumber penerimaan yang telah ada merupakan strategi yang harus segera dilakukan.

\section{Analisis terhadap Kualitas Belanja Publik di Provinsi Kalimantan Timur}

Boex (1999) menjelaskan bahwa expenditure responsibilites merupakan pilar desentralisasi fiskal dari sisi belanja. Dari perspektif belanja, maka daerah diberikan kewenangan melakukan pengeluaran-pengeluaran untuk membiayai fungsi-fungsi pemerintahan yang telah diserahkan kepada daerah. Keputusan untuk melakukan belanja publik tersebut berada di masing-masing daerah karena daerah lebih mengetahui kondisi dan kebutuhan lokal.

Prinsip-prinsip pengelolaan keuangan daerah di Indonesia mengacu pada ketentuan dalam PP Nomor 58 tahun 2005 tentang Pengelolaan Keuangan Daerah. Berdasarkan ketentuan tersebut, pengelolaan keuangan daerah dikelola secara tertib, taat pada peraturan perundang-undangan, efisien, ekonomis, efektif, transparan, dan bertanggung jawab dengan memperhatikan asas keadilan, kepatutan, dan manfaat untuk masyarakat.

Dalam rangka harmonisasi kebijakan pusat dan daerah, maka perencanaan dan pelaksanaan keuangan daerah perlu diselaraskan dengan kebijakan yang diselenggarakan di tingkat pusat. Dengan demikian, prioritas pembangunan di tingkat pusat yang mengacu pada tiga agenda, yaitu pro-growth, pro-poor, dan pro-employment (job creation) perlu pula diselaraskan dengan yang dilakukan di daerah. Untuk mengetahui prioritas-prioritas apa yang dilaksanakan di tingkat daerah, analisa terhadap kebijakan belanja publik di daerah perlu dilakukan. 
Grafik 3 di bawah ini memberikan gambaran perkembangan anggaran belanja Provinsi Kalimantan Timur tahun 2001 sampai dengan 2006.

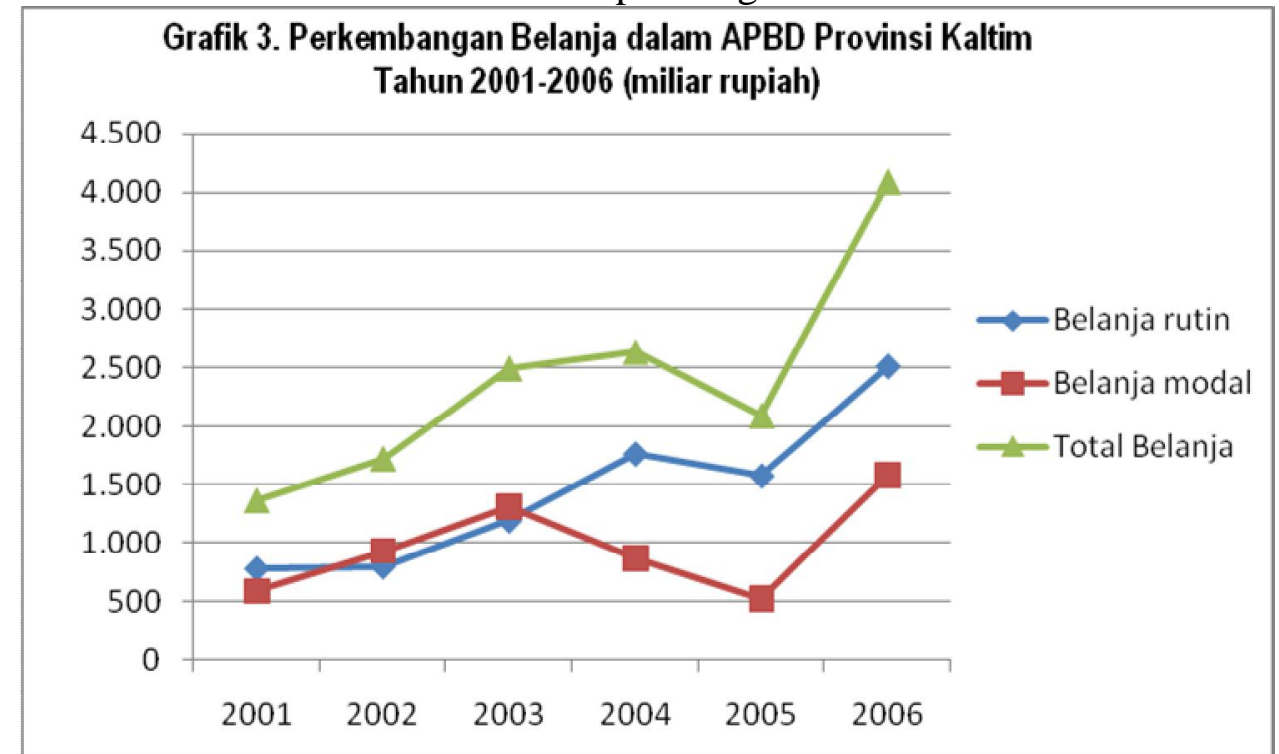

Sumber : Data realisasi APBD, Departemen Keuangan (2007; diolah)

Grafik diatas menggambarkan terjadinya fluktuasi kenaikan dan penurunan belanja dalam APBD Provinsi Kaltim yang cukup tajam. Sejak tahun 2001 hingga 2004 terjadi kenaikan total belanja yang cukup signifikan, yaitu rata-rata sebesar 25 persen. Lonjakan kenaikan yang cukup tajam terjadi pada tahun 2003, yang mencapai 44 persen. Namun, pada tahun 2005 terjadi penurunan pada total belanja sebesar 20 persen bila dibandingkan dengan tahun sebelumnya. Kondisi tersebut menimbulkan pertanyaan bagi segenap kalangan mengingat surplus APBD Provinsi Kaltim tahun 2005 mencapai Rp 2,5 triliun. Kemudian pada tahun 2006 jumlah belanja dalam APBD mengalami peningkatan yang sangat tinggi yaitu mencapai sekitar 95 persen dibandingkan total belanja tahun sebelumnya. Kondisi demikian menyebabkan APBD Provinsi Kaltim mengalami defisit sekitar Rp2 triliun di tahun 2006.

Apabila dianalisa secara spesifik dari sisi belanja rutin dan belanja modal, maka terlihat bahwa belanja rutin masih memiliki proporsi yang lebih besar dibandingkan dengan belanja modal. Kondisi ini hampir sama dengan kondisi yang terjadi di banyak daerah. Apabila dirata-rata sejak tahun 2001 hingga 2006 maka proporsi belanja rutin terhadap total belanja adalah sebesar 59 persen.

Berbeda dengan fitur belanja rutin yang secara konsisten mengalami kenaikan (kecuali di tahun 2005), maka fitur belanja modal menunjukkan pola kenaikan dan penurunan yang cukup dinamis. Pertumbuhan kenaikan belanja modal sejak tahun 2001 hingga 2003 rata-rata mencapai 49 persen, sedangkan pertumbuhan penurunan belanja modal sejak tahun 2004 hingga 2005 mencapai 37 persen. Kemudian, pada tahun 2006 belanja modal mengalami kenaikan yang cukup tajam sehingga mencapai dua kali lipat dari alokasi belanja modal tahun sebelumnya.

Berdasarkan potret belanja dalam APBD selama lima tahun tersebut, kita dapat menilai bahwa Provinsi Kaltim telah berupaya - paling tidak - untuk menyeimbangkan antara porsi belanja rutin dengan porsi belanja modal. Hal ini terlihat dari kenaikan jumlah belanja modal dari tahun 2001 ke tahun 2006 yang mengalami peningkatan hampir tiga kali lipat. Kenaikan ini hanya terpaut sedikit dengan kenaikan belanja rutin.

Namun demikian, apakah alokasi belanja tersebut telah dialokasikan untuk mencapai kesejahteraan rakyat? Hal ini lah yang kemudian menarik untuk dianalisa. 


\section{Analisis terhadap Kapasitas Fiskal terhadap Indikator Ekonomi dan Sosial di Provinsi Kalimantan Timur}

Bagian awal tulisan ini telah memunculkan pertanyaan; Provinsi Kaltim adalah daerah yang kaya, tetapi menurut versi siapa? Pertanyaan tersebut kedengarannya absurd, karena bila kita tinjau dari sisi potensi penerimaan Provinsi Kalimantan Timur maka jawabannya akan mudah dijawab, yakni karena kapasitas fiskal Provinsi Kaltim (terutama dari sektor sumber daya alam) sangat tinggi.

Apabila dibandingkan dengan dua provinsi lainnya (Riau dan DKI Jakarta) maka Kaltim masih menempati urutan yang kedua antara tahun 2005 dan 2006 dari sisi penerimaan Dana Perimbangan dan PAD. Grafik 4 menggambarkan kapasitas fiskal untuk tiga provinsi tersebut.

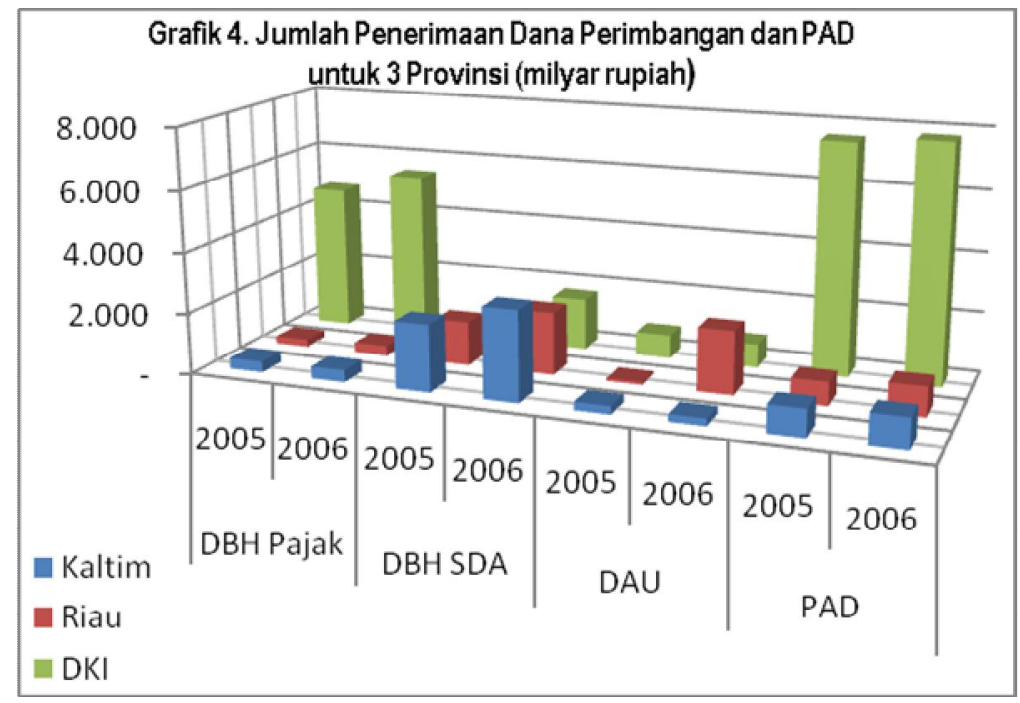

Sumber : data APBD, Departemen Keuangan (2007; diolah)

Dari grafik tersebut dapat diketahui bahwa secara agregat kapasitas fiskal Provinsi DKI Jakarta lebih tinggi sebesar tiga kali lipat dibandingkan dengan Provinsi Kaltim. Hal ini karena DKI diuntungkan dari penerimaan DBH Pajak yang cukup signifikan dan PAD yang sangat tinggi. Selama 2005 dan 2006, penerimaan dari DBH Pajak dan PAD secara rata-rata mencapai 18 persen dan 27 persen terhadap total dana perimbangan (kecuali DAK) dan PAD.

Sedangkan Provinsi Kalimantan Timur memiliki keunggulan komparatif dari sisi penerimaan DBH SDA yang rata-rata mencapai 31 persen terhadap total penerimaan dari DBH, DAU, dan PAD. Penerimaan dari DBH SDA tersebut lebih tinggi sekitar 9 persen bila dibandingkan dengan penerimaan yang diterima oleh Riau. Berbeda dengan daerah lainnya yang menggantungkan penerimaan dari DAU, maka ketergantungan Provinsi Kaltim terhadap DAU tidak signifikan, yaitu hanya sekitar 3 persen saja. Selain itu penerimaan dari PAD memberikan kontribusi yang cukup baik yaitu sekitar 11 persen.

Baru-baru ini Menteri Keuangan menerbitkan mapping peta kapasitas fiskal yang digunakan untuk melakukan penerusan pinjaman luar negeri pemerintah kepada daerah dalam bentuk hibah (PMK Nomor 153/PMK.07/2007). Yang dimaksud dengan kapasitas fiskal disini adalah gambaran kemampuan keuangan daerah yang dicerminkan melalui pendapatan daerah (tidak termasuk DAK, dana darurat, dan penerimaan lain yang penggunaannya dibatasi untuk membiayai pengeluaran tertentu) dikurangi dengan belanja pegawai serta dikaitkan dengan jumlah penduduk miskin. 
Dalam peta kapasitas fiskal tersebut, daerah dikelompokkan berdasarkan indeks kapasitas fiskal sangat tinggi, tinggi, sedang, dan rendah. Berdasarkan peraturan Menteri Keuangan tersebut, Provinsi DKI Jakarta, Provinsi Kaltim, dan Provinsi Kepulauan Riau mendapatkan predikat Sangat Tinggi untuk indeks kapasitas fiskal. Provinsi DKI menduduki peringkat pertama dengan indeks sebesar 8,1160, sedangkan Provinsi Kaltim dan Kepulauan Riau menempati urutan kedua dan ketiga dengan indeks masing-masing 3,8209 dan 3,0161. Provinsi-provinsi lainnya termasuk dalam kategori Tinggi (5 provinsi), Sedang (5 provinsi), dan Rendah (15 provinsi).

Dengan demikian dapat disimpulkan bahwa Provinsi Kaltim dapat dikatakan sebagai daerah kaya apabila kita meninjaunya dari sudut portofolio tersebut. Akan tetapi, apakah kekayaan tersebut telah digunakan untuk kemakmuran rakyat di Kaltim? Berikut ini kita analisa dari sisi kondisi ekonomi dan sosial masyarakat di Kaltim.

Berdasarkan data BPS, angka Produk Domestik Regional Bruto (PDRB) Provinsi Kalimantan Timur pada triwulan III (Juli-September 2007) menunjukkan peningkatan sebesar Rp 53,6 triliun atas dasar harga berlaku dengan migas, sedangkan apabila tanpa migas mencapai sebesar Rp 24,1 triliun (Tribun Samarinda, 2007). Kenaikan tersebut lebih didominasi oleh sektor migas.

Kenaikan tersebut memberikan indikasi bahwa transfer dana dari pusat memberikan pengaruh yang positif terhadap pertumbuhan ekonomi di daerah. Namun demikian, angka pertumbuhan ekonomi yang mengalami peningkatan tersebut seharusnya memberikan gambaran adanya kenaikan penyerapan tenaga kerja dan penurunan jumlah penduduk miskin yang disertai dengan peningkatan kualitas hidup. Akan tetapi, kondisi yang terjadi di Kaltim ternyata tidak sejalan dengan yang seharusnya terjadi.

Penyerapan tenaga kerja yang seharusnya terjadi seiring dengan peningkatan PDRB ternyata menunjukkan hasil yang tidak optimal. Hal ini karena pertumbuhan ekonomi di Kaltim lebih didominasi oleh sektor industri migas yang merupakan padat modal sehingga tidak dapat menyerap tenaga kerja yang cukup besar (Tribun Samarinda, 2007). Sejak tahun 2005 hingga 2006, jumlah pengangguran terbuka justru mengalami peningkatan sebesar 0,94 persen; dari 11,17 persen di tahun 2005 menjadi 12,11 di tahun 2006.

Selain itu, jumlah penduduk miskin pun mengalami peningkatan. Berdasarkan data dari BPS, jumlah penduduk miskin di Provinsi Kaltim antara Juli 2005 dan Maret 2007 mengalami peningkatan. Pada bulan Juli 2005 jumlah penduduk miskin sebesar 299,1 ribu orang atau 10,51 persen. Jumlah ini meningkat menjadi 324,8 ribu atau 11,04 persen pada tahun 2007. Sebaran penduduk miskin lebih besar di daerah perdesaan dibandingkan dengan daerah perkotaan, walaupun secara nominal jumlah penduduk miskin di perdesaan mengalami penurunan dari tahun 2005 ke tahun 2007.

Sedangkan untuk skor Indeks Pembangunan Manusia (IPM) Provinsi Kaltim mengalami peningkatan sebesar 0,32 dari 72,9 di tahun 2005 menjadi 73,3 di tahun 2006. Skor tersebut masih lebih rendah bila dibandingkan dengan Provinsi DI Yogyakarta dan Provinsi Kalimantan Tengah. Bahkan Provinsi Riau menempati peringkat ketiga dalam hal kualitas hidup manusia di daerahnya, dan Provinsi Kaltim menempati peringkat keenam.

Berdasarkan potret indikator ekonomi dan sosial tersebut dapat terlihat bahwa pembelanjaan dana APBD belum dapat mencapai keberhasilan yang optimal, terutama dari sisi indikator sosial. Pertumbuhan ekonomi yang lebih didominasi oleh sektor migas ternyata tidak mampu menyerap jumlah tenaga kerja yang lebih banyak. Dengan tidak optimalnya tingkat penyerapan tenaga kerja maka tingkat kemiskinan penduduk pun sulit untuk dapat diturunkan, bahkan cenderung mengalami peningkatan. 


\section{Sumber Daya Alam dan Climate Change}

Mencermati keunggulan komparatif Provinsi Kaltim terutama dari sisi sektor sumber daya alam (migas) yang merupakan sumber penerimaan terbesar, maka harus disadari sepenuhnya bahwa kekayaan alam yang dimiliki sewaktu-waktu akan habis (depletion). Hal ini karena memang cadangan minyak yang dimiliki jumlahnya tidak signifikan dan usia produksi yang memang sudah habis.

Secara nasional, cadangan minyak (dan batu bara) di negeri ini hanya berkisar antara 0,5-1,3 persen dari total cadangan dunia (Media Indonesia, 2007). Selain itu, ancaman climate change akibat greenhouse effect yang saat ini sedang dikhawatirkan oleh penduduk dunia sebagai senjata pembunuh massal (mass destruction) akan sangat berpengaruh terhadap aktivitas pengeboran minyak dan gas alam. Legget (2005) telah memperingatkan bahwa jika eksplorasi dan pengeboran minyak dan sumber daya mineral lainnya terus dilakukan hingga tingkat yang saat ini sedang dilakukan, maka depresi dan kerusakan ekosistem akan mengancam kelangsungan makhluk hidup dan bahkan kerusakan yang lebih besar daripada senjata pemusnah massal.

Untuk itulah, mungkin Indonesia hanya tinggal menghitung waktu dalam menggantungkan sumber penerimaan dari sektor migas, apabila konversi kepada sumber daya yang lainnya tidak segera direalisasikan. Kondisi demikian tentunya sangat berdampak pada daerah-daerah penghasil yang menggantungkan sumber penerimaannya dari penerimaan migas. Kualitas leadership pemerintahan di daerah sangat krusial dalam mengelola penerimaan dari sumber daya alam -yang dalam ilmu ekonomi disebut sebagai the scarcity of resources- serta menciptakan inovasi baru untuk meningkatkan penerimaan dari sumber yang lain.

\section{The Way Forward}

Bagian sebelumnya telah berusaha menjawab mengenai posisi Kaltim yang dianggap sebagai daerah kaya menurut versi siapa. Persepsi dari sisi kapasitas fiskal dan indikator ekonomi dan sosial menunjukkan perbedaan, sehingga kondisi tersebut memerlukan strategi untuk mengatasinya. Ditambah lagi dengan isu climate change yang akhir-akhir ini menjadi topik pembicaraan global sehingga kebijakan pemerintahan daerah perlu mempertimbangkan kesepakatan-kesepakatan global tentang isu climate change.

Lalu upaya-upaya apakah yang dapat dilakukan untuk mengelola the scarcity of resources tersebut dan bagaimana pengelolaan sumber daya untuk meningkatkan kondisi sosial dan ekonomi masyarakat dalam waktu yang bersamaan?

Pertama, Provinsi Kaltim perlu melakukan intensifikasi penerimaan dari sektor non-migas sehingga tidak hanya bergantung dari penerimaan sektor migas. Apabila kita telaah komponen lapangan usaha yang memberikan kontribusi yang cukup besar terhadap PDRB, maka sektor perdagangan, hotel dan restoran, serta sektor pertanian patut dijadikan pertimbangan dalam melakukan intensifikasi penerimaan. Sektor-sektor tersebut memberikan kontribusi sekitar 3-4 persen terhadap total PDRB Provinsi Kaltim.

Pengembangan investasi memberikan dampak yang paling besar terhadap pertumbuhan ekonomi dan kondisi sosial masyarakat. Kondisi ekonomi global yang menghendaki pembangunan yang bersifat ramah lingkungan akan semakin membatasi ruang gerak untuk melakukan eksplorasi dan pengerukan secara destruktif atas kekayaan alam yang tersedia. Ditambah lagi dengan pertimbangan masa produksi sumur-sumur minyak dan gas yang akan mengalami penurunan produksi (depletion). Oleh karena itu investasi yang perlu ditumbuhkembangkan adalah investasi yang bersifat padat karya, seperti industri manufaktur, industri perdagangan, atau pertanian. 
Industri manufaktur dan perdagangan merupakan lapangan usaha yang mendatangkan banyak multiplier effect (efek berganda). Investasi terhadap kedua jenis lapangan usaha tersebut merupakan jenis usaha padat karya sehingga dampak terhadap peningkatan lapangan kerja dan tingkat pendapatan masyarakat akan terasa secara langsung. Dengan meningkatnya pendapatan masyarakat, maka hal ini akan berdampak pada meningkatnya kemampuan konsumsi masyarakat dan menurunnya angka kemiskinan. Dengan demikian perekonomian daerah juga memberikan dampak kepada kondisi sosial masyarakat.

Untuk itu, pemda selaku pemangku kebijakan strategis di daerah dapat melakukan beberapa hal, antara lain menstimulasi kegiatan industri manufaktur dan perdagangan yang telah ada di wilayahnya dan atau menarik minat investor ke dalam daerah tersebut. Dalam hal memberikan stimulasi terhadap industri yang telah ada, maka peran pemda dapat berupa pemberian bantuan agar bisnis yang ada di wilayah Kaltim semakin kompetitif dan menciptakan iklim yang lebih menunjang untuk perluasan usaha (Suhardjo, 2006). Bantuan yang diberikan dapat berupa pengembangan teknologi, penyediaan sarana pengolahan dan sarana transportasi, ataupun pelatihan-pelatihan yang dapat menunjang proses pengembangan dan kualitas produksi.

Selain itu, sejalan dengan semangat pelaksanaan Inpres Nomor 6 tahun 2007 tentang Kebijakan Percepatan Pengembangan Sektor Riil dan Pemberdayaan Usaha Mikro, Kecil dan Menengah yang dilaksanakan di tingkat pusat, maka pemerintah daerah perlu mengembangkan strategi pemberdayaan usaha riil yang bersifat mikro, kecil dan menengah dengan memberikan kemudahan akses kepada lembaga penyedia modal.

Selain di sektor industri manufaktur dan perdagangan, sektor pertanian dan perkebunan juga merupakan contoh investasi padat karya yang cukup potensial. Dalam investasi tersebut akan melibatkan jumlah tenaga kerja yang cukup besar, mulai dari tahap penanaman hingga tahap masa panen. Oleh karena itu, insentif-insentif perlu diberikan untuk menumbuhkembangkan sektor ini, seperti perijinan, asistensi (baik dalam hal studi kelayakan lingkungan maupun dukungan lainnya), serta bantuan pengembangan teknologi ke arah industri pengolahan yang lebih maju.

Namun demikian, intensifikasi penerimaan tidak hanya dari sektor-sektor tersebut saja. Pemda perlu melakukan intensifikasi penerimaan dari PAD. Secara teori, optimalisasi penerimaan dari sektor perpajakan daerah sangat diperlukan dengan berdasarkan beberapa pertimbangan. Pertimbangan pertama adalah terkait dengan prinsip akuntabilitas terhadap komunitas lokal. Di satu sisi, dengan melakukan pungutan pajak dan retribusi daerah maka pemerintah daerah dituntut untuk dapat mempertanggungjawabkan uang hasil penerimaan tersebut dalam bentuk pemberian pelayanan yang berkualitas. Di sisi lain, masyarakat pun akan mendapatkan keuntungan karena apabila tidak mendapatkan pelayanan sesuai dengan yang diharapkan maka mereka dapat melakukan pengaduan secara langsung kepada pemda sehingga memperpendek jenjang birokrasi. Sebenarnya inilah esensi dari program desentralisasi dan otonomi daerah, yaitu mendekatkan pemerintah kepada rakyatnya.

Pertimbangan kedua adalah sebagai wujud pemberdayaan masyarakat melalui citizen participatory terutama dalam hal penyusunan anggaran. Apabila masyarakat dikenakan pajak dan retribusi daerah maka diharapkan sistem pengawasan masyarakat dapat bekerja secara optimal. Dengan demikian tujuan desentralisasi sebagai sarana untuk mewujudkan demokrasi dapat dicapai apabila mekanisme citizen participatory dapat bekerja secara maksimal. 
Berdasarkan pertimbangan-pertimbangan tersebut, penguatan taxing power perlu diberdayakan secara optimal. Oleh karena itu, pemerintah pusat perlu menyediakan instrumen kebijakan yang mendukung pelaksanaan intensifikasi sektor perpajakan daerah tersebut.

Upaya kedua yang dapat dilakukan adalah dengan menyediakan infrastruktur yang memadai guna menarik minat investor. Berdasarkan pengalaman di beberapa negara maju seperti Inggris, Jerman, dan Amerika Serikat- pemda di negara-negara tersebut gencar melakukan promosi mengenai keunggulan daerahnya masing-masing yang disertai dengan penyediaan infrastruktur yang sangat memadai (Suhardjo, 2006).

Infrastruktur jalan, misalnya, merupakan sarana yang vital dalam menarik minat investor untuk menginvestasikan dananya ke daerah tersebut. Investor selalu mengkalkulasikan biaya transportasi yang harus ditanggung perusahaan apabila investasi akan dilakukan. Untuk itu, mereka akan memperhitungkan dari sisi kecepatan dan keamanan jalur barang yang masuk dan keluar apabila akan melakukan investasi. Selain penyediaan infrastruktur jalan, moda transportasi yang memadai juga perlu diperhatikan pemda untuk memudahkan mobilisasi orang atau barang untuk masuk dan keluar.

Selain sarana infrastruktur jalan, perlu pula diprioritaskan infrastruktur pendukung lainnya yang memadai (pendidikan, kesehatan, dan lainnya) sehingga dapat menampung apabila terjadi peningkatan kapasitas akibat gelombang investasi ke daerah tersebut.

Ketiga, untuk menunjang kemudahan dalam berinvestasi, pemda perlu menciptakan sebuah 'enabling environment' (lingkungan yang kondusif) dengan menyiapkan perangkat peraturan yang kondusif bagi iklim investasi. Perangkat peraturan daerah tentang pajak daerah dan retribusi daerah harus dikaji dari sisi dampak ekonomi dan sosial masyakarakat sehingga bersifat investment friendly.

Dewasa ini gejala euphoria otonomi daerah banyak diimplementasikan secara berlebihan di beberapa daerah. Banyak kebijakan peraturan daerah tentang pajak dan retribusi daerah yang disinyalir mendistorsi perekonomian daerah sehingga mengurangi jumlah investasi karena menimbulkan ekonomi biaya tinggi.

Inpres nomor 6 tahun 2007, yang salah satu programnya adalah peninjauan perdaperda yang menghambat investasi, merupakan wujud konkret kebijakan pemerintah pusat untuk menciptakan iklim investasi yang kondusif dan meningkatan usaha kecil dan menengah. Untuk itu, upaya pengawasan secara represif dan preventif terhadap perdaperda tentang pajak daerah dan retribusi daerah tersebut dilakukan oleh pemerintah pusat dengan melakukan uji material atau evaluasi. Apabila ada perda yang telah ditetapkan oleh pemda atau yang akan ditetapkan oleh pemda secara terbukti melanggar peraturan yang lebih tinggi atau menimbulkan ekonomi biaya tinggi di daerah, maka pemerintah pusat melakukan pembatalan atas perda tersebut.

Di level pemerintah daerah, perlu kiranya dibentuk seperangkat instrumen yang secara profesional memiliki tenaga-tenaga ahli dalam hal perencanaan pajak dan retribusi daerah. Keterlibatan tenaga profesional diperlukan terutama dalam hal melakukan assessment terhadap potensi penerimaan yang dapat dijadikan unggulan daerah tersebut. Tentunya potensi penerimaan tersebut masih dalam koridor jenis pajak dan retribusi daerah yang memang diperuntukkan bagi daerah.

\section{Penutup}

Desentralisasi telah menjadi tren di kalangan negara-negara berkembang di awal tahun 1980-an. Tak terkecuali dengan Indonesia yang memulai program desentralisasi melalui pendekatan 'big bang'. Saat ini pengaturan mengenai program desentralisasi dan 
otonomi daerah diselenggarakan berdsarkan UU No. 32 tahun 2004 tentang Pemerintahan Daerah dan UU No. 33 tentang Perimbangan Keuangan antara Pemerintah Pusat dan Pemerintahan Daerah.

Selama enam tahun pelaksanaan desentralisasi dan otonomi daerah, keberhasilan program tersebut tengah diuji, apakah desentralisasi yang dicanangkan dapat berjalan sesuai dengan yang diharapkan, yaitu memberikan kesejahteraan kepada rakyat? Hal ini karena tujuan pelaksanaan desentralisasi adalah untuk mendekatkan pemerintah kepada rakyat sehingga dapat dicapai efisiensi dalam penyelenggaraan pemerintahan dan peningkatan pelayanan kepada masyarakat.

Kasus per kasus yang terjadi di beberapa daerah masih belum dapat menunjukkan keberhasilan desentralisasi secara signifikan. Bahkan disinyalir tingkat kemiskinan semakin meningkat dan ketidakmerataan yang terjadi antardaerah semakin tinggi. Tak terkecuali fenomena yang terjadi di Provinsi Kalimantan Timur.

Berdasarkan data yang telah disajikan di depan, dari sisi kapasitas fiskal maka Provinsi Kaltim merupakan daerah yang memiliki kapasitas fiskal yang sangat tinggi. Hal ini ditandai dengan tingginya alokasi dana yang diterima oleh provinsi Kaltim terutama dari sisi dana bagi hasil sumber daya alam.

Dari sisi potret belanja, belanja rutin masih mendapatkan alokasi yang besar bila dibandingkan dengan belanja modal. Kondisi ini memang merupakan potret general yang terjadi di banyak daerah. Namun fluktuasi belanja modal yang mengalami kenaikan yang cukup signifikan di tahun 2006 menyebabkan pemda provinsi kaltim memerlukan pembiayaan yang cukup besar sehingga menyebabkan anggaran mengalami defisit. Kondisi ini kontras dengan kondisi sebelumnya yang mengalami surplus yang cukup signifikan.

Hasil analisa diatas menunjukkan bahwa tingginya kapasitas fiskal di Provinsi Kaltim belum memberikan dampak yang positif terhadap kondisi sosial masyarakat. Tingkat pengangguran dan kemiskinan justru mengalami peningkatan. Hal ini bertolak belakang dengan meningkatnya PDRB Provinsi Kaltim.

Berdasarkan kondisi tersebut maka diperlukan kreativitas dan inovasi dari pemda untuk mengembangkan industri dan bisnis yang memberikan kontribusi terhadap pengurangan angka pengangguran dan angka kemiskinan.

\section{Referensi}

Bada Pusat Statistik Provinsi Kalimantan Timur (2007) Tingkat Kemiskinan di Kalimantan Timur 2007. Berita Resmi Statistik Nomor 17/08/64/Th. X, 1 Agustus 2007

Bahl, Roy (1999) Implementation Rules for Fiscal Decentralization. Paper presented in International Studies Program, Andrew Young School of Policy Studies, Georgia

State University. Available online at http://www1.worldbank.org/wbiep/decentralization/Courses/Atlanta\%207.23.01/ bahl1999.pdf

Bahl, Roy and Linn, Johannes F (1992) Urban Public Finance in Developing Countries. New York: Oxford University Press

Bird, Richard M. and Vaillancourt, F (eds) (1999) Fiscal Decentralization in Developing Countries. Cambridge: Cambridge University Press

Boex, Jamie (2001) “An Introductory Overview of Intergovernmental Fiscal Relations". Paper presented in Fiscal Decentralization Workshop in Nepal, International Studies Program, Andrew Young School of Policy Studies, Georgia State 
University. Available online at http://isp-aysps.gsu.edu/training/nepal2004/ boex2001.pdf

Departemen Keuangan (2007) Nota Keuangan dan Rancangan Anggaran Pendapatan dan Belanja Negara Tahun 2008

Kementerian Koordinator Bidang Perekonomian, Departemen Keuangan (2007) Pelengkap Buku Pegangan 2007 Penyelenggaraan Pemerintahan dan Pembangunan Daerah

Legget, Jeremy (2006). Half Gone: Oil, Gas, Hot Air, and the Global Energy Crisis. London: Portobello Books Ltd.

Murniasih, Erny (2006) New Intergovernmental Equalisation Grant in Indonesia: a Panacea or a Plague for Achieving Horizontal Balance Across Regions?. University of Birmingham: International Development Department

No name (2005) Teori, Empiris dan Deskripsi: Trend Internasional dari Desentralisasi Fiskal

Suhardjo, Sussongko, Ir., MSc., MPA., PhD. (2006) Pembangunan Daerah, Mendorong Pemda Berjiwa Bisnis, Jakarta: Penta Rei

Tanzi, Vito (2002) "Pitfalls on the Road to Fiscal Decentralization" in Ehtisham Ahmad and Vito Tanzi. Managing Fiscal Decentralization. Rountledge

White, Roland and Smoke, Paul (2005) "East Asia Decentralizes" in World Bank. East Asia Decentralizes, Making Local Government Work. Washington: World Bank

\section{Peraturan Perundangan}

Undang-undang Nomor 32 tahun 2004 tentang Pemerintahan Daerah

Undang-undang Nomor 33 tahun 2004 tentang Perimbangan Keuangan antara Pemerintah Pusat dan Pemerintahan Daerah

PP Nomor 58 tahun 2005 tentang Pengelolaan Keuangan Daerah

Instruksi Presiden Nomor 6 Tahun 2007 tentang Kebijakan Percepatan Pengembangan Sektor Riil dan Pemberdayaan Usaha Mikro, Kecil dan Menengah

Peraturan Menteri Keuangan Nomor 153/PMK.07/2007 tanggal 27 November 2007 tentang Peta Kapasitas Fiskal Dalam Rangka Penerusan Pinjaman Luar Negeri Pemerintah Kepada Daerah Dalam Bentuk Hibah

\section{Media}

Media Indonesia (2007) Mengalihkan Beban Negara. Edisi Selasa tanggal 4 Desember 2007

Tribun Samarinda (2007) PDRB Naik, Kemiskinan dan Pengguran Juga Naik. Edisi Jumat tanggal 16 November 2007. available online at: http://www.tribunkaltim.com/index.php?option=com_content\&task=view\&id=25 $\underline{33 \& \text { Itemid }=34}$ 